\title{
Virginia Leone Bicudo e Guerreiros Ramos - para uma epistemologia decolonial da perspectiva negro-brasileira nas Américas
}

Virginia Leone Bicudo and Guerreiros Ramos - for a decolonial epistemology from the black-Brazilian perspective in the Americas

Virginia Leone Bicudo et Guerreiros Ramos - pour une épistémologie décoloniale du point de vue noir-brésilien dans les Amériques

\section{Nádia Maria Cardoso da Silva}

\section{(2) OpenEdition}

\section{Journals}

Édition électronique

URL : http://journals.openedition.org/ideas/9758

DOI : $10.4000 /$ ideas. 9758

ISSN : 1950-5701

Éditeur

Institut des Amériques

Référence électronique

Nádia Maria Cardoso da Silva, «Virginia Leone Bicudo e Guerreiros Ramos - para uma epistemologia decolonial da perspectiva negro-brasileira nas Américas », IdeAs [En ligne], 16 | 2020, mis en ligne le 15 octobre 2020, consulté le 18 octobre 2020. URL : http://journals.openedition.org/ideas/9758 ; DOI : https://doi.org/10.4000/ideas.9758

Ce document a été généré automatiquement le 18 octobre 2020.

\section{c) (i) (9)}

IdeAs - Idées d'Amériques est mis à disposition selon les termes de la licence Creative Commons Attribution - Pas d'Utilisation Commerciale - Pas de Modification 4.0 International. 


\title{
Virginia Leone Bicudo e Guerreiros Ramos - para uma epistemologia decolonial da perspectiva negro- brasileira nas Américas
}

\author{
Virginia Leone Bicudo and Guerreiros Ramos - for a decolonial epistemology \\ from the black-Brazilian perspective in the Americas \\ Virginia Leone Bicudo et Guerreiros Ramos - pour une épistémologie décoloniale \\ du point de vue noir-brésilien dans les Amériques
}

Nádia Maria Cardoso da Silva

\section{Introdução}

Para os estudos decoloniais latino-americanos, a noção de colonialidade de poder é de fundamental importância para entender que o mundo não foi totalmente descolonizado, já que a primeira descolonização foi incompleta - ocorrida nos séculos XIX nas colônias espanholas e portuguesa das Américas, e, no século XX, nas colônias inglesas, francesas e portuguesas na Ásia e na África, limitada apenas à independência jurídico-política dos países. Quijano (2005) explica que o período colonial na América Latina não pode ser confundido com colonialidade, pois, colonialismo diz respeito às relações coloniais com administração colonial, enquanto colonialidade se refere à reprodução das relações coloniais e do imaginário racista após a administração/ independência colonial, mantendo, em grande parte, intacta a hierarquia colonial, fundamentada pela ideia de raça. Nesse sentido, a colonialidade de poder nos remete a um cenário no qual os brancos lutam contra a colonização, mas mantêm intacta a hierarquia racial sobre indígenas e negros. Portanto, trata-se de um cenário de independência sem descolonização, no qual há mais repetições no que se refere ao período colonial do que rupturas. Nessa perspectiva, a pequena minoria branca no 
controle dos Estados independentes e das sociedades coloniais latino-americanas como a brasileira, não tinham nenhum interesse social comum com os índios e negros, ao contrário, seus interesses sociais eram explicitamente antagônicos já que seus privilégios se compunham precisamente da opressão desses segmentos. Dessa forma, a colonialidade de poder nos permite compreender a continuidade das formas coloniais de dominação após o fim das administrações coloniais no sistema-mundo capitalista moderno, dizendo respeito a uma relação sócio-cultural hierarquizada entre populações de origem europeias e não-europeias que reproduz as estruturas de poder colonial, nas quais as elites brancas mantêm um sistema de dominação fundamentado pela inferiorização das populações não-europeias.

2 Castro-Gomez S. e Grosfoguel R. (2007:19) explicam que Quijano utiliza a noção de "colonialidade", ao invés de colonialismo por duas razões: "para chamar a atenção sobre as continuidades históricas coloniais e os chamados tempos 'pós-coloniais"' e para "assinalar que as relações coloniais de poder não se limitam só ao domínio econômico-político e jurídico-administrativo dos centros sobre as periferias, mas possuem também uma dimensão epistêmica, quer dizer, cultural". Assim, o projeto político-epistêmico decolonial quer enfrentar esse cenário de independência sem descolonização. Para os estudos decoloniais latino-americanos "a segunda descolonização - à qual nós aludimos com a categoria decolonialidade - tenderá a dirigirse a heterarquia ${ }^{1}$ das múltiplas relações raciais, étnicas, sexuais epistêmicas, econômicas e de gênero que a primeira descolonização deixou intactas" (Castro-Gomez, S.; Grosfoguel, R., 2007: 17). Na colonialidade de poder global, a ideia de raça e racismo se torna o princípio organizador que estrutura todas as múltiplas hierarquias do sistema-mundo. É nesse contexto de um sistema mundo de múltiplas hierarquias de poder que se inclui a hierarquia epistemológica produzindo o eurocentrismo que subalterniza o conhecimento não-europeu ao conhecimento europeu. A articulação da hierarquia racial com a hierarquia epistemológica é fundamental para entendermos a colonialidade de saber/poder. Walsh (2009) enfatiza que a colonialidade de poder ao fundamentar a colonialidade do saber, excluindo as populações não-europeias da construção teórica e discursiva da modernidade, teve na ideia de "raça" uma categoria epistêmica de controle de conhecimentos e de (inter) subjetividades.

3 Assim, se a decolonialidade diz respeito a um devir da superação da colonialidade como contexto marcado pelas heranças racistas/sexistas do colonialismo, a epistemologia decolonial se refere ao enfrentamento da inconclusão da descolonização moderna, no plano epistêmico. Para esse enfrentamento, a epistemologia decolonial pretende narrar as histórias a partir das fronteiras do mundo "moderno", pois, revelam histórias esquecidas que trazem para o primeiro plano uma nova dimensão epistemológica - uma epistemologia da e a partir da margem do sistema mundial colonial moderno. Dessa forma é preciso promover a visibilização daqueles intelectuais situados em lugares de enunciação não privilegiados pela modernidade para resistir aos seus embates imperialistas epistemológicos que ela reproduz, colocando a diferença colonial no centro do processo de produção de conhecimento (Mignolo, W., 2003).

4 A partir da transmodernidade de Dussel (1993), o projeto político-epistêmico decolonial pretende levar a sério o pensamento crítico do Sul Global para ir além da modernidade e de suas estruturas racistas/sexistas epistêmicas. Nesse rastro é que Grosfoguel (2006) propõe tomarmos as cosmologias/visões de pensadores críticos do sul global, que pensam a partir de corpos e lugares étnico-raciais/sexuais subalternizados para uma 
teoria crítica decolonial radical. Dessa perspectiva é possível a elaboração de uma crítica ao ponto de vista universalista, neutro e objetivo que caracteriza os paradigmas eurocêntricos hegemônicos que ao longo dos últimos quinhentos anos inspiraram a filosofia e as ciências ocidentais do "sistema-mundo patriarcal/capitalista/colonial/ moderno.

5 Tomamos a crítica decolonial latino-americana para pensar o racismo/sexismo epistêmico como uma hierarquia de superioridade e inferioridade em torno do conhecimento que assegura o privilégio epistêmico dos homens brancos e heterossexuais de apenas cinco países ocidentais - Itália, França, Inglaterra, Alemanha e Estados Unidos - cujos conhecimentos são tomados como únicos legítimos cientificamente para explicar o mundo inteiro (Grosfoguel, R., 2013). Considerando que para os estudos decoloniais, o racismo-sexismo é estruturante das universidades ocidentalizadas, apresentar os pensamentos e contribuições críticas de dois intelectuais negros invisibilizados e marginalizados nas universidades do Brasil, já é um gesto decolonial, na perspectiva da sua contribuição para a subversão das estruturas epistêmicas de subalternização da colonialidade. Neste artigo apresenta-se uma crítica ao racismo/sexismo epistêmico a partir dos saberes negros silenciados no Brasil. o pensamento crítico de Virgínia Leone Bicudo e Guerreiro Ramos são tomados como perspectivas epistêmicas de decolonialidade do conhecimento, pois, partem de lugares étnico-raciais subalternos e têm potencial para contribuir para a formulação de uma teoria crítica decolonial latino-americana.

\section{Virgínia Leone Bicudo}

6 Filha de mãe imigrante italiana e de pai negro, Virgínia Leone Bicudo nasceu em 1910, na cidade de São Paulo. Seu pai, Teófilo, não conheceu o seu próprio pai e sua mãe desaparecera quando ainda cativa. Nascido do "Ventre Livre"2, em 1888, Teófilo foi criado como empregado na casa dos Bicudos. A condição conquistada de "afilhado" lhe rendeu o sobrenome, mas, o acesso aos estudos foi limitado pelo racismo/sexismo epistêmico: apesar das melhores notas que garantiriam o seu acesso imediato à Faculdade de Medicina, foi impedido por um professor que defendia que aquele não era lugar para preto, experiência que marcou Virgínia profundamente.

7 Intelectual negra silenciada pelas ciências sociais no Brasil, a trajetória de Virgínia Leone Bicudo é privilegiada para nos forçar a pensar na agência das mulheres negras no campo intelectual e seus processos de apagamento. Processos estes que silenciaram a existência de uma mulher negra que ousou entrar num mundo que não era de mulheres negras - o mundo acadêmico-intelectual, especialmente o mundo das ciências sociais que se institucionalizava no Brasil. Pretende-se, neste trabalho, intervir no silenciamento epistêmico de Virgínia Bicudo nas ciências sociais no Brasil, colocando em visibilidade as contribuições pioneiras de uma mulher negra que abriu o campo dos estudos das chamadas relações raciais na sociologia, apesar de ter sido uma subalterna impedida de falar.

8 Virgínia concluiu a graduação na Escola Livre de Sociologia e Política de São Paulo na turma de 1936. Era a única mulher e não havia nenhum homem negro. Sua pesquisa de mestrado, intitulada "Atitudes raciais de pretos e mulatos em São Paulo", vem sendo considerada um trabalho pioneiro sobre relações raciais no Brasil, apesar de guardada desde a sua defesa nos arquivos dessa Escola. Antecede, com competência intelectual, 
estudos de intelectuais canônicos das ciências sociais no Brasil, como Florestan Fernandes e Roger Bastide, desestabilizando teses hegemônicas do momento, como do seu próprio orientador, Donald Pierson e de Gilberto Feyre. De 1941 a 1944, Virgínia entrevistou 31 pessoas, agrupadas segundo os fenótipos ("pretos e mulatos") e as classes sociais ("inferiores e intermediárias"). Assim, se interessa por ouvir dos seus entrevistados sobre seus processos educacionais e familiares e de interações na vida privada e pública, os constrangimentos nas suas trajetórias pessoais e sociais bem como "as estratégias afetivas e matrimoniais, visando fortalecer o grupo ou anulá-lo (casamentos para escurecer ou branquear a raça); as percepções acerca dos sentimentos de beleza, dos afetos, do sofrimento, de inferioridade ou igualdade; os bons e maus modos, públicos e privados, etc" (Silva, M., 2011: 67).

9 Virgínia representa a primeira geração de pesquisadores do Brasil graduados por pesquisadores estrangeiros, a partir da Escola de Chicago, para pensar as relações raciais na sociedade brasileira (Gomes, J., 2013). Instituição pioneira das ciências sociais no Brasil, a Escola de Sociologia e Política (ELSP), foi criada em 1933, pelas elites paulistas, sob forte influência norte-americana, contratando para seu quadro docente, sociólogos e antropólogos estrangeiros. Donald Pierson chega à Bahia em 1935, vindo da Universidade de Chicago (EUA) para pesquisa de campo do seu doutoramento, sob orientação de Robert Park, determinado a avaliar o grau de integração dos negros à sociedade baiana, permanecendo em Salvador até 1937. Robert Park analisa a sociedade dos EUA, defendendo que, no mundo moderno urbano e industrializado daquele momento, os conflitos raciais tendiam a ser substituído pelos conflitos de classe, pois, tais conflitos ainda persistiam naquela sociedade porque ela estava saindo de uma ordem escravocrata e de casta, para uma sociedade de classes, na qual os negros teriam mais chances de ascenderem socialmente. Além disso, para a Escola de Chicago quando os indivíduos não se identificavam com a questão racial e nem se organizavam em entidades negras de luta contra o racismo, caso do Brasil para Pierson, não existia raça nem racismo (Bacelar, J., 1997).

10 O orientador de Virgínia, Pierson, vai se inspirar nesse discurso da Escola de Chicago sobre a sociedade americana para analisar a Bahia, estendendo sua análise para o Brasil. Mas não apenas, também se inspira na interpretação hegemônica do Brasil, naquele momento representado por Gilberto Freyre. Assim, Pierson, à maneira de Freyre, defende que o racismo não estrutura a sociedade brasileira, pois, não há hierarquias raciais, o que há são vestígios de preconceito racial devido à proximidade do contexto dos anos 30 com a escravidão no Brasil, à maneira de Park e da Escola de Chicago. Para Pierson a dificuldade enfrentada pelos negros "é um problema econômico e educacional e, de nenhum modo um problema racial" (Pierson, D., 1971:53). Considerando que a sociedade brasileira se encontrava em transição para uma sociedade estruturada exclusivamente pela classe social, negras e negros terão maior mobilidade social. Em resumo, a principal tese defendida por Pierson é que a cor das pessoas pouco pesava na determinação de sua posição social na sociedade baiana e brasileira da década de 30.0 Doutorado de Pierson o consolidou definitivamente como cientista social de prestígio, tanto no Brasil quanto nos $\mathrm{EUA}^{3}$. É assim que, em 1939, Pierson vem ao Brasil para articular o Departamento de Sociologia/Antropologia da jovem Escola de Sociologia e Política, revigorando o campo dos estudos sobre o negro e instaurando no Brasil a sociologia das relações raciais. 
11 O inusitado do trabalho acadêmico de Virginia Bicudo é que, pela primeira vez, nas ciências sociais do Brasil, negras e negros surgem não como objeto, mas como sujeitos falantes, narrando suas experiências em um contexto social marcado por profundas heranças coloniais. A epistemologia decolonial em Virgínia aparece quando opera essa ruptura com o racismo/sexismo epistêmico das ciências sociais nas quais negras e negros estavam epistemicamente silenciados como objeto. Ao posicionar seus pensamentos no centro da sua tese ela está, de forma inaugural, contribuindo para subverter as estruturas coloniais presentes nos processos de produção de conhecimento no Brasil, cujo efeito de seus poderes tem desvalorizado o pensamento de negras e negros. Ao colocá-los para falar na sua tese, interpreta o Brasil a partir de corpos e lugares étnico-raciais/sexuais subalternizados, como quer os estudos decoloniais latino-americanos. Assim, está evidenciando histórias e narrativas negras esquecidas nas margens/fronteiras da sociedade brasileiras e colocando a diferença negra no centro da sua produção de conhecimento.

Visando tornar visível a contribuição intelectual de Virgínia às ciências sociais no Brasil, aqui escolhemos apresentá-la, principalmente, através das mulheres as quais entrevistou - "pretas" e "mulatas" de classes "inferiores" e "intermediárias". Embora Virgínia não tenha problematizado a intersecção raça/classe e gênero no seu trabalho, no entanto, entrevistou 17 mulheres negras do total das suas 31 entrevistas, a maioria concentradas nas classes inferiores, enquanto os homens negros concentram-se nas classes médias - seis dos sete entrevistados das classes inferiores eram mulheres. Seu trabalho nos permite constatar que as mulheres negras estavam majoritariamente nas mais baixas posições de uma sociedade profundamente estruturada por raça e gênero. Virgínia apresenta relatos de mulheres negras que, após apostarem no casamento inter-racial como estratégia de fuga da discriminação, vivenciam discriminações raciais praticadas pelos seus próprios parceiros brancos, demonstrando que o convívio interracial pode não eliminar atitudes racistas:

Naturalidade ou igualdade no trato dos brancos com as pessoas de cor, não há (...)Não tenho experiências pessoais desagradáveis porque fugi do negro (...) Se eu fosse branca seria mais feliz no casamento (...) vejo o aborrecimento do meu marido por eu ser de cor: passado o período de forte entusiasmo afetivo, ele começou a sentir uma espécie de desapontamento por me ter como esposa. Demonstra pena ou vergonha quando observa algum traço físico nos filhos. Estes sentimentos dele me ofendem, e nos põem em conflito.

(Bicudo, V., 2010:112)

13 As mulheres que falam na tese de Virgínia são mulheres "pretas" da classe social "inferior" como Antônia que trabalha como empregada doméstica e é analfabeta: "Não quero mais saber de ligações com 'patrícios'. Fui criada por branco. Minha madrinha dizia sempre - 'Por que os pretos não se unem para conseguir vida melhor'. Hoje vejo que a raça de cor não tem união, porque cada um quer ser mais do que o outro" (Bicudo, V., 2010:68). Já Justina, também, "preta” e empregada doméstica diz que quase não tem relações com "gente de cor", pois "são pessoas invejosas, deseja ver-nos sempre mal economicamente ou lutando com doenças; então ficam satisfeitos", após enfatizar que se dá melhor com vizinhos brancos, conclui: 'Desejaria ser branca, mas que fazer...Não me sinto infeliz por ser preta, mas pelas dificuldades econômicas e pela doença de mamãe" (Bicudo, V., 2010:69).

14 A maioria das mulheres negras escutadas por Virgínia Bicudo além de se encontrarem nas mais baixas posições sociais, possuem menos consciência negra e são mais afetadas 
por processos de inferiorização e alienação de si. No entanto, há pretas pobres e analfabetas, como a cozinheira Benedita que afirma que: "Não gosto de ver preto casar com branco, é fazer pouco caso do preto" (Bicudo, V., 2010:68/69). Ou outra "preta" cozinheira, casada com um "mulato empregado doméstico" que afirma achar "os pretos mais orgulhosos do que os brancos", pois, tem" uma vizinha mulata 'grã-fina', veste-se bem e só se dá com grã-finos, apenas cumprimenta os vizinhos pretos", concluindo: "Muitas vezes senti orgulho dos patrões, mas acho maior o orgulho entre pretos de melhor situação" (Bicudo V., 2010:70). Já a "preta" analfabeta, empregada doméstica, solteira diz: "O branco faz pouco caso de preto por causa da cor (...) Nas lojas da cidade, quando a gente entra para comprar alguma coisa, só é atendida depois de muito esperar" (Bicudo, V., 2010:70/71).

15 As mulheres voltam a falar quando Virgínia mapeia os casos de "mulatos das classes sociais “inferiores'”. Assim, "uma moça de 18 anos de idade de cor parda (...) filha ilegítima de mãe preta e pai pardo", cozinheira, que fez até o $3^{\circ}$ grau primário, relata a reprodução de práticas racistas dentro da própria família:

Tenho gênio diferente de minha irmã, que desobedece à mamãe. Ela é orgulhosa, xinga-me de negra, diz que não é minha irmã. Meu pai era pardo, o dela era português, por isso ela despreza. Ela quer casar-se com brancos e só namora brancos. Xinga de negros aos irmãos. Não gosta de andar conosco na rua. Quando saímos juntos, ela anda afastada dos outros.

(Bicudo V., 2010: 104)

Essa moça ainda afirma que diferente de sua irmã pretende se casar com um "patrício" para não ser criticada pelos brancos:

Já ouvi branco falar de minha irmã, quando acompanhada de um namorado branco: 'bandeira paulista', disseram. Fico nervosa ouvindo tais coisas, então prefiro casarme com um preto. Uma família de italianos, vizinhos, proíbe os filhos de chegarem à minha casa por questão de cor: certa vez castigaram as crianças porque aceitaram pão da minha casa. (Bicudo, V., 2010:104)

17 Já a "entrevistada, filha de pai branco italiano, lenheiro e mãe preta cozinheira, com 32 anos de idade, casada com um rapaz branco, sapateiro, filho de italianos", que ficou "órfã de pai aos 8 anos, tendo de deixar o grupo escolar e passar a trabalhar na fábrica até os 19 anos", relata: "Vivo só, não frequento bailes. A gente de cor não presta, não melhora, não é gente unida; quando melhoram a posição, procuram branco para casar. É preciso clarear a raça".

Ao apresentar os nove casos de "mulatos das classes intermediárias", Bicudo, V. (2010:110) entrevista quatro mulheres negras de classe média que evidenciam que a ascensão social não lhes garante uma vida sem discriminação racial e sem internalização da inferiorização. A primeira é uma mulher considerada "parda, solteira", que diz que "considera-se branca, exibindo com orgulho a sobrinha de pele branca", já sobre o sobrinho pardo, diz: "Não sei por que este saiu moreninho". A segunda entrevistada de Virgínia é "uma moça parda de 28 anos de idade, solteira", funcionária pública com curso secundário que diz: "A cor motiva grande complexo de inferioridade, a gente se sente inferior ao branco, feia, diferente, e muitas vezes tem vergonha de si mesmo. Consequentemente, manifesta-se o retraimento, um sentimento de humildade, levando a pessoa a evitar a aparecer. Pelo desprezo, os brancos nos colocam nessa situação" (Bicudo V., 2010:110). Essa mesma moça expõe ainda o auto ódio étnico-racial produzido pelo sentimento de inferioridade, ao concluir que: 
Não ando em companhia de pretos ou mulatos (...) Convenci de que não sou preta, apenas descendo de pretos pelo lado paterno (...) Evito a companhia de preto e do mulato, por ser um deles, por vergonha (...) Não seria capaz de amar um preto ou um mulato, mas, desde que não se perceba traços de ascendência preta, eu me casaria com tal pessoa (...) Nas atitudes com namorado, deixo que ele resolva se me quer ou não. Se eu fosse branca não seria tão submissa, mas tomaria a iniciativa para encaminhar ao casamento.

(Bicudo V., 2010:111)

19 A terceira "é uma senhora parda de 31 anos de idade, casada com um branco, professor do curso secundário" que diz que "naturalidade ou igualdade no trato do branco com as pessoas de cor, não há", para logo depois afirmar que: "Não tenho experiências sociais desagradáveis, porque fugi muito do negro, e, como mulata, procurei me assemelhar ao branco". No entanto, relata discriminação pelo marido branco por ela ser "de cor" (Bicudo, V., 2010:112). A quarta entrevistada é "uma mulata de 25 anos de idade, solteira, residindo com os pais", funcionária pública que diz que:

(...) os pretos estão em situação muito inferior no sentido de educação e instrução. Tão inferior que nem procuram reagir, mais descem cada vez mais, entregando-se ao álcool e aos bailes. Para o mulato há duas situações: uma parte dos mulatos se integra no meio negro e a outra no meio de brancos, procurando valorizar-se dado o preconceito do branco. o branco tem preconceito para com as características de cor. Sinto que existe preconceito contra mim, mas não demonstram porque são educadas; sou tratada como igual, porém tenho certeza que no íntimo as pessoas são diferentes, pelo menos nos ambientes em que estive, no ginásio e atualmente no trabalho. Consequentemente, evito a companhia de pretos e mulatos.

(Bicudo, V., 2010:118)

20 Ao apresentar as narrativas das mulheres negras e suas vivências de discriminação racial nos seus casamentos inter-raciais, Virgínia confronta a tese de seu orientador Pierson de que “a miscigenação(...) principalmente quando ligada a intercasamento, resulta em laços sentimentais entre pais filhos, laços que obstam o aparecimento de atitudes de preconceito de raça e ao mesmo tempo colocam o mestiço em posição favorável a ascensão social"“ (Bicudo, V., 2010:156). As/os entrevistadas/os de Virgínia, também contrariam as teses sociológicas tanto de Pierson quanto da escola paulista de sociologia de que o problema central no Brasil é de classe, pois, à medida que os negros ascendessem socialmente, seriam integrados à sociedade brasileira. Elas/es demonstram consciência de que quanto mais ascendem socialmente, mais são discriminados: "O problema racial é muito sério, principalmente no nível social em que estou; é pior do que no nível mais baixo. Quanto mais inteligente, mas se sente e se sofre (...) Há firmas brasileiras que não aceitam empregados de cor" (Bicudo, V., 2010:116). Também aparece nos depoimentos, o esforço empreendido pelos negros que ascendem socialmente para serem considerados iguais:

Vejo-me sempre empenhado em demonstrar valor próprio, que sou inteligente e em conquistar a amizade, para eliminar contra mim conceitos como o de que 'negro, quando não suja na entrada, suja na saída' (...) o preconceito limita meu círculo social, e fico revoltado(...) Em consequência do preconceito, não vejo nenhum grande futuro para mim (...) Não posso frequentar boas sociedades de nível superior à que tenho.

Os falantes decoloniais de Virgínia ainda relatam vários casos de impedimento de acesso a restaurantes, festas, clubes, etc, evidenciando viverem em uma sociedade segregada no Brasil da década de 40 , que vai se hierarquizando racialmente: 
Sob minha chefia trabalhavam vários moços. Certo dia, um deles entregava-me um convite de festa de formatura em presença de sua irmã. No dia seguinte, conta-me ingenuamente o rapaz: "Ontem minha irmã ficou preocupada vendo-me convidá-lo para a festa de formatura e me censurou. Tranquilizei-a imediatamente, dizendolhe que o havia convidado porque sabia que o senhor não iria."

(Bicudo, V., 2010:73-74)

A epistemologia decolonial volta a aparecer no trabalho de Virgínia quando, através da fala dos seus entrevistados, fica evidenciada a continuidade das hierarquias coloniais na nossa colonialidade de poderes - o colonial presente no "pós-colonial" - na qual o racismo vai estruturando a desvantagem negra e o privilégio branco no Brasil, na primeira metade do século XX. A entrevista de "um homem preto, funcionário público e profissional liberal", nos permite constatar as hierarquias raciais da colonialidade de poderes em que vivia a sociedade brasileira dos anos 40 :

Procedendo a um inquérito, encontramos a maioria dos negros passando privações terríveis: grande número de desempregados, morando mal acomodados em porões imundos, na promiscuidade que favorece a destruição moral da família. Pelas pesquisas realizadas por nós, $80 \%$ dos negros da Capital, não exerce profissão definida. O negro é meio carpinteiro, meio mecânico, meia colher, nunca chegando a ser oficial completo, ajudante distou ou daquilo. Após a abolição precisando de um meio de vida, intitularam-se "ganhadores". Hoje não há grande diferença da natureza dos serviços dos negros de 50 anos atrás. Apenas os de hoje intitulam-se "biscateiros". Entretanto, encontramos negros profissionais competentes: mecânico, carpinteiro, eletricista, datilógrafo, taquígrafo, liberais. Mas não há serviços para eles. As ocupações dos negros são engraxates, ensacador, estafeta, faxineiro, contínuo, motorista, motorneiro, guarda-noturno, guarda-civil, cozinheiro, ferroviário, etc.

(Bicudo V., 2010: 126)

23 Assim Virgínia apresenta um cenário de colonialidade de poder no Brasil, sem ainda ter sido nomeado por Quijano (2005). Através das narrativas coletadas por Virgínia podemos constatar que diante da ascensão social, as barreiras raciais vão se tornando mais marcantes. Os limites de acesso ao mercado de trabalho, por exemplo, vão consolidando a pobreza negra e a riqueza branca na colonialidade dos poderes no Brasil:

Concluímos por meio de inquéritos, que entre nós, vários estabelecimentos comerciais não aceitavam negros para seus serviços, fosse qual fosse a capacidade oferecida. As mulheres é que minoravam a situação, trabalhando como empregadas domésticas e levando as sobras de comida da casa dos patrões. Em uma casa comercial que pedia empregados, depois de um preto ter demonstrado capacidade para correspondente, teve a resposta: "o Sr. tem competência, mas é pena, não aceitamos elementos de cor."

(Bicudo V., 2010: 116)

24 A linha de cor, conceito desenvolvido pelo sociólogo negro Du Bois (1999) para pensar as barreiras raciais na sociedade estadunidense, para Pierson era inviável como conceito operacional para interpretar as distâncias sociais entre negros e brancos no Brasil, pois, considerava à maneira de Freyre, que a miscigenação desintegrou a linha de cor entre nós brasileiros e, mais do que isso, que um severo processo de miscigenação que estava a caminho no Brasil, iria provocar o desaparecimento tanto do indígena quanto do negro, acabando com o preconceito ao acabar com o negro (Gomes, J., 2013). Quando Virgínia dá visibilidade na sua tese, às narrativas de negras e negros de classe média expondo o racismo e as profundas barreiras raciais que vivem no Brasil dos anos 40, apesar da ascensão social conquistada através da educação, está 
contribuindo para a afirmação da existência de uma linha de cor no Brasil e para uma crítica aos pressupostos da Escola de Chicago, especialmente, quando aplicados ao contexto brasileiro de "relações raciais".

Somente anos depois da defesa do mestrado de Virgínia, ocorrida em 1945, o psiquiatra martinicano, Frantz Fanon, publica sua tese de doutorado, Pele Negra, Máscaras Brancas, em 1952. No entanto, semelhante a Fanon, mas sete anos antes, Virgínia Bicudo já se mostrava preocupada com os efeitos psicológicos da vivência do racismo pelos negros em processos de interação social com brancos, diagnosticando uma inferioridade introjetada e expressa através do desejo de conviver com o branco que, quando frustrado, tende ou a se embranquecer, procurando casamentos inter-raciais, por exemplo, ou a desaparecer, através de atitudes de isolamento. Vários dos falantes de Bicudo (2010) expõem a escravização negra de sua inferioridade: "acho que o negro é uma raça sem futuro, evito andar em companhia deles" (Bicudo, V., 2010:119); "negro não confiava no próprio negro (...) o preto não procura o consultório de preto por desprezo" (Bicudo V., 2010:132); "Não existe preconceito do branco contra o preto, pois, é o próprio preto que faz surgir situações de desprezo para ele, devido a suas atitudes inferiores. O preto só pensa em dançar. É preciso instruir o negro para melhorar suas atitudes e, então, ser aceito pelo branco" (Bicudo, V., 2010:95); "Só possuo relações sociais com brancos. As sociedades de brancos nos vedam participar como sócios. $\mathrm{O}$ preto deve viver separado do branco. Acho que o mulato deve evoluir, casando sempre com branco, para extinguir a raça" (Bicudo, V., 2010:95). Gomes J. (2013:99) ressalta que enquanto Fanon se interessa pela desalienação do negro, Virgínia preocupa-se com o porquê e como a alienação de si ocorre pelo complexo de inferioridade e a falta de uma consciência racial, chamando a atenção também para a antecipação de alguns aspectos do pensamento fanoniano por Virgínia Bicudo - ambos investigam o drama negro de "ir ao mundo dos brancos", compartilham de um "certo universo conceitual" (ideias como complexo de inferioridade, assimilação, atitudes, conflitos, consciência de cor, etc). Além disso, Gomes (2013:100) nos lembra que Fanon teve inicialmente sua tese rechaçada pela academia francesa e Virgínia a sua dissertação esquecida na biblioteca da Escola Livre de Sociologia e Política e do pensamento social brasileiro.

O que isso sugere é que podemos localizar em Virgínia signos de uma epistemologia pós-colonial, considerando a importância dos estudos e temas de Fanon para a consolidação desse campo. Mas, assim como Fanon (2005) que apresenta a luta contra o colonialismo e seu racismo como a terceira via dos condenados da terra, para além de embranquecer ou desaparecer, Virgínia Bicudo evidencia a luta política dos negros para enfrentar esse racismo no Brasil da década de 30, através de uma de suas principais organizações - a Frente Negra Brasileira (FNB). Ao entrevistar seus ativistas e analisar seu Jornal A Voz da Raça, portanto, coloca em visibilidade seus pensamentos críticos. É um desses entrevistados de Bicudo V. (2010: 72-73) que tem a ousadia de contestar a principal tese do orientador dela, Donald Pierson, e, posteriormente, Virgínia tem a ousadia de publicá-la:

A questão racial, no Brasil, prende-se à queda do regime escravocrata, com a abolição da escravatura, que acarretou a ruína de muitos fazendeiros. Vendo-se arruinados, os fazendeiros investiam injustamente seu ódio contra negro, como é facilmente verificado nas cidades fastigiosas do interior. Em São Paulo, o preconceito parece gerado pelo convívio com imigrantes. Afirma-se na Bahia, como fez o professor Pierson, que o negro rico não sofre preconceitos (sic). Tal afirmação não é verdadeira em São Paulo. Em primeiro lugar, pode-se afirmar que não existe negro economicamente independente; portanto, aqui entendemos por negro rico 
aquele que for instruído, educado. As experiências diárias mostram que também eles sofrem as consequências da cor da pele. O Centro dos Funcionários Públicos vedou a entrada a moças formadas em nossas escolas secundárias, filhas de um intelectual que entre nós exerce suas funçõ es, unicamente por se tratar de pessoas de cor.

Virgínia, foi a primeira pesquisadora no Brasil que se interessou em evidenciar uma associação reivindicativa de negros e seu jornal. Com esse gesto de deixar os ativistas anti-racistas falarem no Brasil da década de 40, contraria novamente a tese de seu orientador Donaldo Pierson, quando defende que a ausência de organizações associativas de negros em Salvador, era mais uma evidência de que o racismo não era uma questão importante no Brasil. A Frente Negra Brasileira era organizada nacionalmente como um partido político negro, inclusive na Bahia, mas fechada na ditadura Vargas em 1937. Gomes (2013) e os próprios entrevistados de Virgínia se referem a diversas outras organizações negras na década de 40 .

Virgínia contribui com a epistemologia decolonial quando explicita que o subalterno negro no Brasil vem falando desde pelos menos a década de 40, mas não vêm sendo ouvido. Além disso, desmonta o esquema étnico-racialmente hierárquico da relação sujeito-objeto, da epistemologia ocidental, especialmente euro-americana, desafiando a tradição eurocêntrica das práticas sócio-antropológicas dos intelectuais brasileiros que se fundamenta na lógica sujeito-branco e objeto-negro. No entanto, Virgínia Leone Bicudo era totalmente invisível tanto para a academia quanto para os movimentos negros e de mulheres negras, até a publicação de sua Dissertação, em 2010, no centenário de seu nascimento, pela Editora Sociologia e Política. Será que a tese de Virgínia não "teria" que ser esquecida ao desmanchar no ar tanto com a tese da democracia racial freyriana, antes do Projeto Unesco, quanto com a tese que vai se hegemonizando a partir de Pierson, de submissão da raça/cor à classe pela escola paulista de sociologia, especialmente por Florestan Fernandes e do francês Roger Bastide? Para Tavoralo (2011:339) a contundência com que Virgínia sustenta a presença marcante da discriminação racial no Brasil, é o aspecto que merece destaque, pois "essa posição contrariava a interpretação que atribuía às desigualdades raciais causas relacionadas com as diferenças de classe". A política de esquecimento da contribuição intelectual de Virgínia Bicudo foi flagrantemente acionada na publicação dos resultados da Pesquisa Unesco. Ciclo de pesquisas sobre relações raciais no Brasil, realizadas nos anos 50, encomendadas pela Organização das Nações Unidades para a Educação, Ciência e Cultura (UNESCO), que num contexto de pós-segunda guerra, sob impacto das consequências do nazismo/fascismo no mundo, "em meio ao debate sob o valor heurístico do conceito de raça", concebe o Brasil "como um laboratório que atestaria cientificamente uma sociedade sem raças" (Maio, M., 2015:606). Tal ciclo de pesquisa, influenciado pelo sucesso internacional das obras de Gilberto Freyre e de Pierson, já parte da tese de que a sociedade brasileira é um caso exemplar de sociedade multirracial e étnica com convivência harmônica e tem como perspectiva comparar a excepcionalidade do Brasil em relação às experiências de segregação racial da África do Sul e dos Estados Unidos. Para tanto articula uma "rede transatlântica de cientistas sociais" para desenvolver pesquisas, tanto em âmbito rural e urbano dos estados do Rio de Janeiro, São Paulo, Pernambuco e Bahia, "gerando um novo, amplo e diversificado quadro interpretativo das relações raciais no Brasil" (Maio, M., 2015). Bicudo quanto seus colegas Oracy Nogueira e Aniela Ginsberg foram pesquisadores do 
Projeto Unesco/Anhembi (1951-1953). Os resultados das pesquisas foram publicados na primeira edição do livro Relações Raciais entre Negros e Brancos em São Paulo (1955), marco dos estudos das relações raciais no Brasil que evidenciam a existência do preconceito racial em São Paulo, organizado por Roger Bastide e Florestan Fernandes. No entanto, seus trabalhos foram publicados na primeira edição do livro como um "apêndice" do estudo no qual Roger Bastide e Florestan Fernandes aparecem como organizadores e autores. Intitulado Atitudes dos alunos dos grupos escolares em relação a cor de seus colegas (1955), a pesquisa de Virgínia é resultado de questionários aplicados com mais de 4520 crianças de 09 a 15 anos de 108 escolas públicas de São Paulo (SP), considerando a educação escolar como campo privilegiado de contatos raciais, e de entrevistas com 29 famílias desses estudantes (operárias brancas). Na pesquisa, Virgínia Bicudo busca analisar as atitudes de rejeição/aceitação dos colegas brancos em relação aos estudantes negros e a influência das famílias para tanto. Focando sua análise nas atitudes de brancos e de forma secundária nas pessoas de cor, Virgínia demostra a existência de uma preferência generalizada pelo branco. Já o mulato surge como o grupo menos escolhido e com maior identificação com os brancos. Atitudes de autorejeição e de internalização de inferioridade já apareciam na maioria das crianças negras, especialmente nas meninas. As crianças rejeitavam a discriminação com base na cor, mas associavam aos brancos o que é bom, e os negros ao que é mau. Portanto, é uma pesquisa que exibe as preferências e rejeições baseadas na cor ainda na infância.

Na segunda edição de Relações Raciais entre Negros e Brancos em São Paulo (1959), as contribuições de Virgínia e dos seus dois colegas foram retiradas completamente da publicação, figurando apenas Florestan Fernandes e Bastide como autores e organizadores. Braga (2016) enfatiza que "(..) o efeito para a história dessa publicação é que esse importante estudo será lembrado como obra exclusiva da 'escola paulista' da Universidade de São Paulo, em detrimento da produção dos autores da Escola Livre de Sociologia e Política", chamando a atenção para os impactos sobre Virgínia da "falta de reconhecimento de seu protagonismo" e de "ter sido colocada de maneira secundária justamente numa área em que foi pioneira". Campos L. (2016:623) ressalta que "o leitor que hoje comprar uma das edições posteriores do livro só terá acesso a uma versão incompleta da obra que influenciou tantas discussões sobre a questão racial entre as décadas de 1950 e 1980" e ainda que " do trio excluído das reedições Relações Raciais entre Negros e Brancos em São Paulo, Oracy Nogueira é provavelmente o mais influente nos estudos posteriores sobre o tema" (Op Cit, p. 625). Virgínia e Aniela eram as duas únicas mulheres pesquisadoras do Projeto Unesco e ambas, no momento, eram professoras de Psicologia Social da Escola Livre de Sociologia e Política. Aniela era polonesa radicada no Brasil e Virgínia única mulher negra do Projeto Unesco. A partir daí, Florestan Fernandes da Escola de Sociologia da Universidade de São Paulo se tornou referência nacional no estudo sociológico de relações raciais no Brasil, publicando A integração do negro na sociedade de classes, em 1965, ainda como resultado das pesquisas do Projeto Unesco/Anhembi ${ }^{5}$.

31 Virgínia afirma ter escolhido a sociologia para se proteger da discriminação racial que vivenciou desde sua experiência escolar na infância ${ }^{6}$ e que barrou seu pai em se tornar médico. No entanto, a sociologia foi mais um campo no qual racismo/sexismo a afetou através de seu silenciamento. A aproximação de Virgínia Bicudo com a Psicanálise se iniciou quando ainda estudava na Escola Livre de Sociologia e Política, através da disciplina de Psicologia Social. Virgínia foi a primeira mulher que fez análise na América Latina, em 1937, passando a lecionar Higiene Mental e Psicanálise na Escola 
Livre de Sociologia e Política, nos anos de 1940. Frustrada com a sociologia, a Psicanálise, foi se tornando o campo de procura de Virgínia para entender-se como um corpo de negra no mundo: “eu fui buscar defesas científicas para o íntimo, o psíquico, para conciliar a pessoa de dentro com a de fora. Fui procurar na sociologia a explicação para questões de status social. E na psicanálise, proteção para a expectativa de rejeição" (entrevista de Virgínia a Anna Verônica Mautner e Luiz Meyer, outubro de 1983 apud Braga, 2016). Mas a fundadora do estudo sociológico das relações raciais, foi se afastando desse campo a ponto de recusar convite para o Seminário O Negro no Ensino Superior alegando que "não tinha mais interesse em discutir o tema das relações raciais nem de expor sua intimidade, além de se encontrar bastante doente" (Gomes J., 2013:118)

32 A psicanálise foi se tornando cada vez mais o campo de fuga da invisibilidade em que Virgínia foi submetida na Sociologia, consolidando seu brilhantismo e pionerismo intelectual e ativista - foi fundadora da Sociedade Brasileira de Psicanálise de São Paulo, da Sociedade de Psicanálise de Brasília e da Revista Brasileira de Psicanálise. No I Congresso Latino-Americano de Saúde Mental, em 1954, Virgínia foi severamente constrangida pelos acadêmicos da Psiquiatria da Universidade de São Paulo (USP) por atuar como psicanalista não sendo médica, através da circulação de panfletos que diziam: "Se eres neurótico e queres se tornar psicótico, procura a doutora Virgínia Bicudo. Se trate com a doutora Virgínia Bicudo" (Braga, A., 2016:11). Espaço masculino e branco, precisaríamos colocar a psicanálise brasileira no divã para entender qual impacto de ser mulher e negra exerceu nesses ataques: “(...) estrangeira, tantas vezes, nos espaços em que circulou e desbravou, mesmo estando no seu país. Os ataques que recebeu por ser não médica entre os médicos, não homem num universo marcadamente masculino, por ser não branca num universo que fazia questão de ser tão branco" (Braga, A., 2016:15).

33 Na sociologia, Virgínia Bicudo foi uma pesquisadora radicalmente decolonial, pois foi uma mulher e negra que não contente em ter a ousadia de estar na recente instituição universitária brasileira, colonialmente estruturada pelo racismo/sexismo, num momento em que o normal era a ausência dos corpos e pensamentos de mulheres e de negros, ainda produz uma pesquisa que desafia a alta hierarquia dos poderes brancos da colonialidade epistêmica das ciências sociais do Brasil. o lugar epistêmico de mulher negra foi determinante para ser a primeira intelectual brasileira nas ciências sociais a descontruir o poderoso consenso freyriano de democracia racial brasileira, explicitando de forma pioneira como a cor era um poderoso fator de hierarquização da colonialidade de poder no Brasil.

Contemporâneos, podemos ver que Guerreiro Ramos e Virgínia Bicudo têm muitos pontos em comum. Ambos foram profundamente silenciados e esquecidos no ambiente acadêmico-universitário das ciências sociais do Brasil, forçando-os a migrarem para outras áreas, nas quais se tornaram intelectuais de referência: Guerreiro Ramos se torna professor titular do Programa de Doutorado em Administração Pública da Universidade do Sul da Califórnia, atuando junto à maior escola de Administração do mundo - School of Public Administration - e Virgínia é intelectual-chave na institucionalização da Psicanálise no Brasil. Muitos autores, que recentemente passaram a se interessar por Guerreiro, falam em uma solidão intelectual. Schwartzman (1983) reconhece a solidão desse intelectual negro na década de 50 no Brasil, enfatizando que o trabalho intelectual de Guerreiro se deu de forma quase 
isolada, pois, fora do ambiente acadêmico, não tinha sustentação institucional. Oliveira, L. (1995:9), que elaborou um dos melhores trabalhos sobre Guerreiro, reconhece isso ao afirmar que seu livro "traz um sentido de homenagem a este intelectual que reagiu aos cânones da institucionalização das ciências sociais no Brasil e talvez por isso mesmo tenha sido esquecido, marginalizado, excluído do panteão dos cientistas socais brasileiros". Figueiredo A. e Grosfoguel R. (2007: 37) analisam a trajetória de Guerreiro Ramos para ilustrar o quanto tem sido difícil consolidar uma intelectualidade negra na universidade brasileira, chamando a atenção para o fato de que foi construída no Brasil, uma "política do esquecimento" da contribuição de Guerreiro no âmbito acadêmico. 0 próprio Guerreiro Ramos tinha consciência da geopolítica acadêmica de sua exclusão e silenciamento na universidade brasileira, dominada pela hegemonia da escola paulista de sociologia, pois, assim diz:

Se você fizer uma análise, da situação da ciência social no Brasil até o momento em que eu começo a escrever, ela é dominada por São Paulo. Depois São Paulo perde a influência. Então vem o IBESP, e o meu pensamento empolga todo mundo. Eles mudam, vem para um negócio mais prático, mais concreto. Eu sou silenciado durante 15 anos.

(Oliveira L., 1995:171)

Assim como Virgínia, Guerreiro também, a partir de sua inserção no Teatro Experimental do Negro, passa a se preocupar com os processos que tornam as negras e negros escravizados pelo sentimento de inferioridade, marca profundamente cunhada sobre nós pelo colonialismo português escravista. $O$ trabalho de Virgínia fortalece as posições de Guerreiro quando critica os socio-antropólogos brancos brasileiros que estudam o negro fixando num outro- não-ser, portanto, impossível, para um Brasil da década de 50, que se queria "desenvolvido". Exemplo das marcas dessa inferiorização negra para afirmar a superioridade branca no Brasil, é dado pelo depoimento do entrevistado de Bicudo V. (2010:152), no qual afirma que geralmente o maior inimigo do negro são os branco-mestiços, "branco neto de preto", utilizando as palavras "desprezo", "desdém", "pouco caso" e " desprestígio" para se referir à como os negros eram cotidianamente tratados. Guerreiro Ramos tomou conhecimento do trabalho de Virgínia, e, mais do que isso, expôs os resultados da sua pesquisa no Jornal Quilombo do TEN, em artigo intitulado Contatos Raciais, bem como os mencionou em suas palestras (Gomes, J., 2013:117).

\section{Guerreiro Ramos}

Alberto Guerreiro Ramos nasceu em Santo Amaro da Purificação na Bahia, em 1915. Seu pai, Vitor Juvenal Ramos, nasceu escravizado em 1873, quando já em vigor a Lei do Ventre Livre, e sua mãe, Romana Guerreiro Ramos, nasceu em Angola e foi traficada para o Brasil como escravizada. Após a morte de seu pai, a mãe de Guerreiro vem para a capital da Bahia, Salvador, tornando-se lavadeira para famílias de elites locais que o estimularam em seus estudos (Maia, J., 2015).

Para apresentar o pensamento de Guerreiro Ramos, será proposto um diálogo com o pensamento de Franz Fanon, evidenciando convergências entre esses dois intelectuais oriundos da América Latina e Caribenha, fato que inscreve o Brasil na cartografia do pós-colonial e decolonial antes da emergência desses estudos. Como leitor de Sartre, liderança intelectual do Instituto Superior de Estudos Brasileiros (ISEB) - importante centro de estudo, ensino e divulgação das ciências sociais no Brasil, na década de 50 - e 
ativista do Teatro Experimental do Negro (TEN), Guerreiro parece ter tomado conhecimento da obra de Fanon, pois percebemos vários pontos de proximidade no pensamento deles. Um dos livros de Fanon mais conhecidos, Pele Negra, Máscaras Brancas foi publicado num momento em que a interpretação do Brasil por Guerreiro estava em efervescência. Nessa perspectiva, Maia J. (2015:51), assinala que o movimento epistemológico de Guerreiro Ramos, entre os anos de 1953 a 1964, é caracterizado pela centralidade do colonialismo nas suas reflexões, tratado como intrínseco à estrutura das ciências sociais, já que coloca em evidência que "a própria construção da questão do negro no Brasil, deriva de uma agenda das ciências sociais colonizadas". Tal movimento de Guerreiro Ramos, segundo o qual “a crítica ao racismo é na verdade, uma crítica às ciências sociais e seu discurso moderno", para Maia, J. (2015:51), “ganha sentido à luz dos escritos terceiro-mundistas que, na década de 1950, vinham evidenciando a dimensão colonial das ciências humanas europeias - caso de Frantz Fanon, por exemplo". Ressaltando que Guerreiro Ramos faz uma virada periférica no seu pensamento nesse momento, atribui tal virada à sua experiência no TEN, mas também ao "encontro do autor com protagonistas da luta anticolonial em Paris, quando de uma viagem realizada em 1956", momento no qual "a capital francesa era um verdadeiro centro de intelectuais africanos e caribenhos das colônias que logravam constituir laços de solidariedade transcontinental justamente no coração da Metrópole colonizadora". Maia J. (2015: 51) defende que a partir de tal viagem, Guerreiro passa escrever artigos para jornais "defendendo o espírito de Bandung7 e inserindo os problemas brasileiros nos temas mais gerais da luta anti-imperialista e da situação do Terceiro Mundo".

Assim, tanto Guerreiro quanto Fanon, falam a partir do lugar de intelectuais periféricos preocupados com os impactos do colonialismo racializado na subjetividade dos colonizados. Em Pele, Fanon analisa criticamente os cânones da ciência ocidental, buscando avaliar sua funcionalidade para entender a experiência negra. Dessa forma, apesar de se fundamentar na epistemologia ocidental para formular sua compreensão dessa experiência, também aponta os limites dela. Por sua vez, Guerreiro preocupa-se com a importação pelos cientistas sociais brasileiros, das teorias produzidas na Europa e nos EUA, aplicadas de forma acrítica para se pensar o Brasil, país com fortes marcas herdadas da opressão colonial europeia. Para Guerreiro, a socioantropologia produzida no Brasil, por esse seu caráter de colonialidade de saber-poder, é uma ideologia da brancura que vinha oprimindo os negros e negras brasileiros.

Fanon F. (2005:26) abre o Pele... constatando que “o negro não é um homem”, pois é instalado numa zona de não-ser - "região extraordinariamente estéril e árida". Afirma, de imediato, que seu projeto intelectual é "liberar o homem de cor de si próprio" (Fanon, F., 2005:26), já que “ o negro quer ser branco" como efeito do poder de uma branquitude que se apresenta como a única condição de acesso à humanidade - o "branco incita-se a assumir a condição de ser humano" (Fanon, F., 2005:27). Constatando a infelicidade do negro que deseja embranquecer, Fanon F. (2008:28) afirma que "para o negro há apenas um destino: E ele é branco". Embranquecer é a estratégia para não desaparecer, e assim vai sendo construído, para Fanon, o processo social de alienação dos negros, assentado num complexo de inferioridade, produzido por um duplo processo de dominação: inicialmente por uma exploração econômica, em seguida pela "interiorização, ou melhor, pela epidermização da inferioridade" (Fanon F., 2008:28). Para o êxito do processo de "epidermização" dessa inferioridade, a ciência foi uma aliada fundamental do projeto europeu de colonização racializada do mundo, pois o comportamento patológico do negro na relação com negros e brancos, para 
Fanon (2005, p. 33) é "consequência direta da aventura colonial", alimentada pela " sua veia principal no coração das diversas teorias que fizeram do negro o meio do caminho no desenvolvimento do macaco até o homem" pois "já foi dito que o preto é o elo entre o macaco e o homem; o homem branco, é claro" (Fanon F., 2005:43).

Fanon F. (2005:59) constata existir no negro "uma tentativa de fugir à sua individualidade, de aniquilar seu estar-aqui", além de "uma exacerbação afetiva, uma raiva em se sentir pequeno, uma incapacidade de qualquer comunhão que o confina em um isolamento intolerável" (Fanon, F., 2005:59). Constata ainda que, não podendo se satisfazer no seu isolamento, para o negro, "só existe uma porta de saída, que dá no mundo branco" pois "ser branco é como ser rico, como ser bonito, como ser inteligente" (Fanon, F., 2005:60). Assim, colonização, ciência e racismo faz com que o negro frequentemente reproduza "quase que integralmente uma constelação delirante que toca o domínio do patológico" na atitude diante do branco ou do seu semelhante: "o preto inferiorizado passa da insegurança humilhante à auto-acusação levada até o desespero" (Fanon, F., 2005:66).

Guerreiro Ramos A. (1995: 1995), por sua vez, afirma que "o desejo de ser branco afeta fortemente os nativos governados por europeus", provocando um "desvio existencial" que observa "em toda parte em que populações negras estão sendo europeizadas", pois: “(...) o negro europeizado, via de regra, detesta mesmo referências à sua condição racial. Ele tende a negar-se como um negro, e um psicanalista descobriu nos sonhos dos negros brasileiros forte tendência para mudar de pele". Aqui constatamos que as convergências de pensamento são impressionantes, pois Fanon também, em Pele..., registra os sonhos dos seus pacientes de fugir de sua pele. Fanon F. (2008:29) quer analisar para destruir o que ele chama de "a assunção em massa do complexo psicoexistencial" dos negros, produzidos pelo colonialismo e pelo racismo, pois, "a civilização branca, a cultura europeia, impuseram ao negro um desvio existencial" (Fanon, F., 2008:31). Assim, como Guerreiro, Fanon F. (2008:31) também é um intelectual comprometido com a transformação das sociedades de seu tempo histórico, afetadas pelo processo europeu de colonização racializada do mundo, assumindo que sua produção intelectual é historicamente situada: "A arquitetura do presente trabalho situa-se na temporalidade (...). Sendo ideal que o presente sempre sirva para construir o futuro. E esse futuro não é cósmico, é o do meu século, do meu país, da minha existência (...) Pertenço irredutivelmente à minha época. E é para ela que devo viver".

Fanon F. (2008:49) afirma que seu propósito é a desalienação dos negros, e isso implica "uma súbita tomada de consciência das realidades econômicas e sociais" (Fanon, F., 2008:28). Seu projeto intelectual-ativista é declaradamente anunciado, pois, apesar de considerar que "seria fácil provar que o negro é igual ao branco", afirma que seu objetivo é outro: "O que nós queremos é ajudar o negro a se libertar do arsenal de complexos germinados no seio da situação colonial (Fanon, F., 2008:44). Guerreiro, por sua vez, quer desalienar a ciência social no Brasil pois, "para ganhar em autenticidade, terá de libertar-se da postura alienada ou consular que a tem marcado", podendo, só assim, se transformar numa tarefa científica criadora. Guerreiro Ramos A. (1995:196) se refere a um "problema" da ciência social brasileira - "uma alienação, uma forma mórbida de psicologia coletiva, a patologia social do brasileiro e do baiano, principalmente", no que diz respeito ao negro, que "resultam de uma falta de suficiência da comunidade, do auto-desprezo, de um sentimento coletivo de inferioridade(...)". Guerreiro detecta uma patologia social que afeta, principalmente, os 
intelectuais "brancos" brasileiros, pois, apesar de todos mestiços, apresentam um sentimento de inferioridade por sua matriz africana e de superioridade em relação aos negros e negras, por sua matriz europeia. Como estratégia de disfarce dessa origem negra e de aproximação com essa desejada superioridade branco-europeia, tematizam o negro a partir da "transplantação" teórico-epistemológica euro-americana, fixando-o num lugar de seu Outro. Por isso que Guerreiro quer desalienar a sociologia, pois, é aí que o negro brasileiro é inventado como um ser exótico, estático, paralisado, estranho, ou seja, um absolutamente outro do branco para afirmar a branquitude brasileira. A branquitude, também para Fanon (2008), apresenta um "comportamento patológico", segundo uma "psicologia inumana".

Além de atuar produzindo teoria para intervir na forma como os negros vinham sendo representados pelas ciências sociais brasileiras, Guerreiro começa, a partir de 1948, também a intervir nas práxis, quando passa integrar os quadros de ativistas do TEN. Sua preocupação tanto teórica quanto ativista também era a reconstrução da subjetividade de negros e negras recalcadas por uma sociedade que produzia "um complexo psico-existencial". Guerreiro, atua no TEN utilizando as técnicas da psicologia social para reconstrução da subjetividade dos negros afetados pelo sentimento de inferioridade e ressentimentos provocados pela experiência da colonização, escravidão racial e do racismo no Brasil. Nesse momento em que esteve filiado ao TEN, a partir de seu diagnóstico da "psicologia diferencial do negro" e do "ressentimento" mantido por estes em relação aos negros de status social superior, bem como em relação aos brancos e mulatos, Guerreiro propôs "técnicas sociológicas" para libertar os negros das amarras da brancura e para que afirmassem sua negritude. Esta seria uma modalidade de psicologia social a fim de promover uma reconstrução subjetiva do negro.

Guerreiro via o Brasil como uma sociedade que, ainda que independente e republicana, saída recentemente de 3 séculos de escravização racial, mantinha um forte sistema de inferiorização e de exclusão dessas pessoas do processo de modernização capitalista ainda como heranças coloniais. Ambos preocupados com os danos subjetivos gerados por esses processos, buscam enfrentá-los. No entanto, enquanto Fanon utiliza sua medicina, especialmente, a psicoterapia para isso, Guerreiro utiliza o teatro, o psicodrama, o sociodrama como caminho, influenciado pelo TEN, criando o que denominava de Grupoterapia - através do teatro, oportunizava para negros e negras pobres, o enfrentamento de medos e ressentimentos gerados pela condição de escravidão e racismo para superação dos estereótipos raciais e das visões autodepreciativas. Transpondo para o palco, as situações de preconceito e conflitos concretas, vividos cotidianamente, o Grupoterapia visava interferir na auto-imagem dos negros na medida em que oportunizava vivências para libertá-los das tensões emocionais oriundas do racismo que viviam no Brasil dos anos 40 e 50.

O nacionalismo de Guerreiro é apontado como um dos fatores do seu ofuscamento. No entanto, a nação em Guerreiro, além de ser uma herança do ISEB, é considerada uma categoria fundamental para os intelectuais periféricos, como ressalta Ortiz (1985). A nação em Guerreiro deve ser entendida num contexto internacional em que os nacionais das sociedades colonizadas lutavam contra a colonização europeia em busca da libertação nacional. Para Guerreiro, o nacionalismo faz sentido naquele contexto de Brasil em que permanecia a colonialidade nas relações sócio-econômicas e na produção de conhecimento, especialmente nas ciências sociais, mas também um cenário de transformações, propício para a descolonização das mentalidades tanto intelectuais - 
na medida em que produzissem uma "sociologia nacional" - quanto populares, na medida em que desenvolvessem uma maior consciência crítica sobre suas condições. A nação também fez todo sentido para Fanon, pois era uma categoria fundamental para os intelectuais periféricos preocupados com os impactos da colonização nas sociedades. Ortiz (1985) chama a atenção para isso ao fazer um exercício de identificar os pontos de aproximação entre Fanon e o ISEB, fundamentando a potência decolonial em Guerreiro, na medida em que, ao alinhar o pensamento do ISEB com o de Fanon - considerando que Guerreiro foi fundador, presidente e peça-chave do ISEB - ele indiretamente alinha o pensamento de Guerreiro a este que foi o inaugurador das teorias pós-coloniais e decoloniais do ponto de vista epistemológico. O ISEB já herda essa potência decolonial ao utilizar semelhantes temas, semelhantes conceitos, mesmas preocupações políticas de Fanon, firmando um lugar de fala - um lugar intelectual "colonizado" que fala a partir da periferia do mundo (Ortiz, R., 1985).

Tanto Fanon quanto Guerreiro não consideram que a afirmação da negritude é suficiente para enfrentar o racismo. Eles colocam os brancos também na cena dos afetados psicologicamente pelo colonialismo. Para Fanon, se o negro "vive submerso pelo desejo de ser branco é que vive numa sociedade que torna possível seu complexo de inferioridade, em uma sociedade cuja consistência depende da manutenção desse complexo, em uma sociedade que afirma a superioridade de uma raça" (Fanon, F., 2005:95). Por sua vez, Guerreiro ao lado de Virgínia Bicudo (na sua pesquisa do Projeto Unesco), inauguram no Brasil os estudos da branquitude. Guerreiro Ramos coloca a brancura como obstáculo para organização da nação, faz o mesmo diagnóstico de Fanon em Pele..., sobre a representação branca sobre os negros, e atribui a uma atitude imperialista a classificação da brancura com atributos enobrecedores e da negritude com atributos pejorativos, afirmando que não se identificando com o contexto étnico do pais, há um protesto racial dos brancos brasileiros, elaborado em nome da ciência e de uma sociologia alienada dos problemas nacionais.

É olhando para o branco brasileiro que Guerreiro identifica seu sentimento de vergonha com as origens raciais da população do Brasil e dele mesmo. E foi através da política do embranquecimento que os cientistas sociais branco-mestiços brasileiros escolheram resolver "o problema do negro no Brasil". Como Guerreiro que afirmou que não existe "problema do negro" no Brasil, confrontando com a forma como era colocada a questão racial pelos cientistas sociais brasileiros e identificando que o que existe é um problema da sociologia no Brasil com o negro, Fanon diz: "Falo, aqui, por um lado de negros alienados (mistificados) e por outro de brancos não menos alienados (mistificadores e mistificados) (...) não existe problema negro. Ou pelo menos, se existe, os brancos não se interessam por ele senão por acaso" (Fanon, F., 2008:43).

As aproximações entre o pensamento de Guerreiro Ramos e o de Frantz Fanon fortalecem o argumento decolonial presente na obra de Guerreiro Ramos desde a décadas de 50 no Brasil. Defendo que Guerreiro Ramos antecipou o pensamento decolonial, mais do que isso, proponho que Guerreiro seja considerado fundador dos estudos decoloniais, especialmente, de uma perspectiva negra, assim como Fanon é considerado o fundador dos estudos pós-coloniais no mundo. Pode-se fundamentar essa defesa também pela epistemologia decolonial que se apresenta na produção intelectual de Guerreiro Ramos ainda nos anos 50, marcadamente pelo pensamento crítico que produz a partir de corpo/lugar de negro subalternizado do Sul Global; por sua crítica à importação das teorias europeias e estadunidenses para pensar o Brasil e o negro, pois 
tais teorias não levavam em conta a singularidade de uma país como o Brasil independente, mas não descolonizado - afirmando que quando importamos teorias euro-americanas, estamos importando o seu imperialismo, antecipando, assim, Spivak (2010); por sua afirmação de um lugar negro de fala imprescindível de ser assumido, inclusive pelos branco-mestiços brasileiros, se quiserem compreender de forma decolonial a situação do negro no Brasil.

E por fim, Guerreiro ressalta que é no ativismo negro brasileiro que se vinha exercitando um conhecimento socio-antropológico efetivamente decolonial sobre os negros e negras. Resultado do amadurecimento de ideias presentes em diversas manifestações dos movimentos negros no Brasil, para Guerreiro Ramos A. (1995:205), o Teatro Experimental do Negro foi o primeiro lugar a desenvolver práticas políticointelectuais de enfrentamento à colonialidade de saber-poder no Brasil, denunciando "a alienação da antropologia e da sociologia nacional, focalizando a gente de cor, à luz do pitoresco ou do histórico puramente, como se se tratasse de elemento estático ou mumificado". Portanto, desde 1944, o TEN vem se constituindo na "manifestação mais consciente e espetacular da nova fase, característica pelo fato de que, no presente, o negro se recusa a servir de mero tema de dissertações 'antropológicas', e passa a agihjr no sentido de desmascarar os preconceitos de cor" (Ramos, A., 1995:205).

Assim, Guerreiro apontou o racismo/sexismo epistêmico das ciências sociais no Brasil constituídas hegemonicamente de homens brancos - que, ao tornar o negro objeto, inventa um negro brasileiro - estático, exótico, mumificado, problemático. Aliás, se aproxima de Fanon (2005), de Said (1990) e de Bhabha (2007) nessa ideia da "invenção" do subalterno como Outro, mas ainda quando identifica que o conhecimento que as ciências sociais produziram no Brasil, sobre nós, negros e negras, é baseado na "lógica" do estereótipo. Guerreiro afirma ainda um lugar negro de fala imprescindível de ser assumido, inclusive pelos branco-mestiços brasileiros se quiserem compreender efetivamente a situação do negro no Brasil. Defende a necessidade de que os estudos sobre o negro no Brasil se dêem de forma comprometida com a transformação social das suas condições precárias de vida.

51 Guerreiro foi um intelectual que foi vítima do racismo/sexismo epistêmico produzido pela colonialidade epistemológica da vida acadêmico-universitária brasileira. Portanto, seguir a trilha da sua trajetória intelectual, nos permite expor de forma crítica esse racismo/sexismo epistêmico, como querem os estudos decoloniais. No entanto, ainda que vítima, Guerreiro Ramos deixa nú esse racismo/seximo epistêmico ao explicitá-lo nas ciências sociais brasileiras, dominadas epistemicamente por homens brancos que estudam negras e negros como problema. Inspirada na música Negro Drama, dos Racionais MC, podemos dizer que Guerreiro era a "carne" que passou a ser a "navalha". Mas ainda como "carne" e "navalha", consegue se firmar como um devirdescolonização, apontando caminhos para combater o racismo/sexismo epistêmico. A universidade brasileira, latino-americana e caribenha do século XXI, precisa urgentemente garantir um lugar de fala para esse Guerreiro.

\section{Conclusão}

Em suma, Virgínia e Guerreiro fazem parte da geração dos primeiros cientistas sociais no Brasil, e foram alvos de uma poderosa operação de silenciamento, apesar de produzirem contribuições intelectuais de importância fundamental para se 
compreenderem o Brasil e a América Latina. Em plena década de 40, Virgínia e Guerreiro adotaram perspectivas críticas decoloniais para pensar as permanências das estruturas coloniais na sociedade brasileira. Ambos são os nossos ancestrais de uma tradição de pensamento negro decolonial que se apresenta nas comunidades negras contemporâneas - nos quilombos, nos ativismos anti-racistas, nos terreiros de candomblé e nas rodas de capoeira - pois, anda que afetados pela colonialidade dos poderes, produziram epistemologia de existências, reexistências e de resistências no Brasil.

\section{BIBLIOGRAPHIE}

Bacelar, Jeferson, Donald Pierson e os brancos e pretos na Bahia, Horiz, Antropol, Porto Alegre, vol 3, n 7, p. 129-143, nov. 1997. Disponível em internet: https://www.scielo.br/pdf/ha/ v3n7/0104-7183-ha-3-7-0129.pdf, Acesso em 20 junho 2020.

Bhabha, Homi, O local da cultura, Belo Horizonte, Editora UFMG, 2007.

Bicudo, Virgínia Leone, Atitudes raciais de pretos e mulatos em São Paulo, São Paulo, Editora Sociologia e Política, 2010.

Bicudo, Virgínia Leone, Atitudes dos alunos dos grupos escolares em relação a cor seus colegas, in: Bastide, Roger, Fernandes, Florestan, eds. (1955), Relações Raciais entre Negros e Brancos em São Paulo, São Paulo, UNESCO/Anhembi.

Braga, Ana Paula Musatti, Pelas trilhas de Virgínia Bicudo: psicanálise e relações raciais em São Paulo, 2016, Disponível em internet: https://revistalacuna.com/tag/virginia-bicudo/, Acesso em 20 junho 2020.

Castro-Gómez, Santiago y Grosfoguel, Ramón, Prólogo: Giro decolonial, teoría crítica y pensamiento heterárquico, in: Castro-Gómez, S., Grosfoguel, R. (Orgs.), El giro decolonial: reflexiones para una diversidad epistémica más allá del capitalismo global, Bogotá, Siglo del Hombre Editores, Instituto Pensar, 2007, p. 9-23. Disponível em internet: http://www.unsa.edu.ar/histocat/ hamoderna/grosfoguelcastrogomez.pdf, Acesso em jul-2015.

Campos, Luiz Augusto, «Relações Raciais entre Negros e Brancos em São Paulo: a história de uma edição ", Revista Estudos Políticos: a publicação eletrônica semestral do Laboratório de Estudos Hum(e) anos (UFF), Rio de Janeiro, vol. 6, n² 2, p. 620-627, setembro 2016. Disponível em: http:// revistaestudospoliticos.com/, acesso em: 29 junho 2020.

Du bois, W.E.B, As almas da gente negra, traduzido do inglês por Heloísa Toller Gomes, [ed. orig. The Souls of Black Folk, Chicago, A. C. McClurg \& Co, 1903], Rio de Janeiro, Lacerda Editora, 1999.

Dussel, Enrique, 1492: o encobrimento do outro (a origem do mito da modernidade), traduzido por Jaime A. Clasen, [ed. orig. 1492: El encubrimiento del Outro. Hacia elorigen del mito de la Modernidad, Madrid, Nueva Utopía, 1992], Petrópolis (RJ), Vozes, 1993.

Fanon, Frantz, Pele Negra, Máscaras Brancas, Salvador, EdUfba, 2008.

Fanon, Frantz, Os Condenados da Terra. Juiz de fora: Ed. UFJF, 2005. (Coleção cultura, vol 2) 
Figueiredo, Angela, Grosfoguel, Ramón, Por que não Guerreiro Ramos? Novos desafios a serem enfrentados pelas universidades públicas brasileiras, Cienc. Cult., São Paulo, vol. 59, n², p. 36-41, June 2007.

Maia, João Marcelo Ehlert, A Sociologia Periférica de Guerreiro Ramos, in: Centro de Estudos e Pesquisas em Humanidade da UFBA (CRH), Dossiê: Sociologia Periférica e Questão Racial revisitando Guerreiro Ramos, Salvador, UFBA, 2015.

Maio, Marcos Chor, Lopes, Thiago Da Costa, Entre Chicago e Salvador: Donald Pierson e o estudo das relações raciais, Estud. hist. (Rio J.), Rio de Janeiro, vol. 30, n 60, p. 115-140, abr. 2017, disponível em internet: https://www.scielo.br/scielo.php?

pid=S0103-21862017000100115\&script=sci_abstract\&tlng=pt, acesso em 20 de junho 2020.

Maio, Marcos Chor, Cor, intelectuais e nação na sociologia de Guerreiro Ramos, Cad. EBAPE.BR, Rio de Janeiro, vol. 13, nº spe, p. 605-630, sept. 2015.

Mignolo, Walter, Histórias locais/Projetos globais - Colonialidade, saberes subalternos e pensamento liminar, tradução Oliveira, Solange Ribeiro de, Coleção Humanitas, Belo Horozonte, UFMG, 2003.

Gomes, Janaína, Os Segredos de Virgínia: estudo de atitudes raciais em São Paulo (1945-1955), Programa de Pós-graduação em Antropologia Social, Universidade de São Paulo, 2013.

Gahyva, Helga, Atitudes raciais de pretos e mulatos em São Paulo, Horiz, antropol., Porto Alegre, vol. 17, n 36, p. 296-300, dec. 2011. Disponível em internet: https://www.scielo.br/scielo.php? pid=S0104-71832011000200015\&script=sci_arttext, acesso em 20 de junho de 2020.

Grosfoguel, Ramon, La descolonización de la economía política y los estudios postcoloniales: transmodernidad, pensamiento fronterizo y colonialidad global, Revista Tabula Rasa, $\mathrm{n}^{\circ}$ 4, p.17- 48, janjun. 2006. Disponível em internet: https://www.revistatabularasa.org/numero04/ladescolonizacion-de-la-economia-politica-y-los-estudios-postcoloniales-transmodernidadpensamiento-fronterizo-y-colonialidad-global/, acesso 11/10/2020.

Grosfoguel, Ramón, Racismo/sexismo epistémico, universidades occidentalizadas y los cuatro genocidios/ epistemicidios del largo siglo XVI, Tabula Rasa, Bogotá, n 19, p. 31-58, dec. 2013. Disponível em: http://www.scielo.org.co/scielo.php? script=sci_arttext\&pid=S1794-24892013000200002\&lng=en\&nrm=iso, acesso em 20 de Junho de 2020.

Ortiz, Renato, Cultura Brasileira e Identidade Nacional, São Paulo, Brasiliense, 1985, p. 51.

Pierson, Donald, Brancos e pretos na Bahia: estudo de contato racial, São Paulo, Ed. Nacional, 1971.

Oliveira, Lúcia Lippi, A sociologia do Guerreiro, Rio de Janeiro: Ed. da UFRJ, 1995.

Ramos, Alberto Guerreiro, Introdução crítica à sociologia brasileira, 2ª , Edição, Rio de Janeiro, Editora da UFRJ, 1995.

Said, Edward, Orientalismo - O Oriente como invenção do Ocidente, São Paulo, Companhia das Letras, 1990.

Shwartzman, Simon, A sociologia de Guerreiro Ramos, Revista de Administração Pública, 17, p. 30-34, abril-hun, 1983.

Silva, Mário Augusto Medeiros da, Reabilitando Virgínia Leone Bicudo, Soc. Estado, Brasília, vol. $26, \mathrm{n}^{\circ} 2$, p. 435-445, aug. 2011.

Spivak, Gayatri, Pode o subalterno falar?, Belo Horizonte, UFMG, 2010. 
Tavolaro, Lília Gonçalves Magalhães, Tempo soc., São Paulo, vol. 23, n² 2, p. 339-340, nov. 2011. Disponível em internet: https://www.scielo.br/scielo.php?

script=sci_arttext\&pid=S0103-20702011000200016, acesso em 20 junho 2020.

Walsh, Catherine, Interculturalidad, Estado, sociedad: luchas (de) coloniales de nuestra época, Quito, UASB/Abya-Yala, 2009.

\section{NOTES}

1. Heterarquia é um conceito forjado pelo sociólogo grego Kryakos Kontopoulos (1993) para se referir a uma linguagem capaz de pensar os sistemas de poder como uma série de dispositivos heterônomos vinculados em rede ou ainda "estruturas complexas nas quais não existe um nível básico que governa os demais, já que todos os níveis exercem algum grau de influência mútua em diferentes aspectos particulares e atendendo a conjunturas históricas específicas"(Castro-Gomez S.; Grosfoguel, R., 2015: 18).

2. Promulgada em 1871, a Lei do Ventre Livre determinava que os filhos de mulheres escravizadas nascidos a partir daí, ficariam livres, no entanto, sem terem condições de viver em liberdade sem suas mães que permaneciam escravizadas, eram criados no regime da escravização racial.

3. A tese de Pierson foi publicada pela Universidade de Chicago com o título Negroes in Brazil: A study of race contact at Bahia, no ano de 1942, recebendo o prêmio Anisfield Award como "melhor livro científico e erudito publicado neste ano no campo das relações raciais" nos EUA, e obtendo “ os mais eloquentes aplausos da intelectualidade brasileira" (BACELAR, 1997, p. 130). Em 1945 foi publicada em português, com o título de Brancos e pretos na Bahia: estudos de contato racial, livro que é reeditado em 1971.

4. Tal posição foi defendida por Pierson, de acordo com Virgínia (2010, p.156) ao falar sobre miscigenação, em sua primeira Conferência "O Negro no Brasil" na Escola Livre de Sociologia e Política de São Paulo. Já na segunda Conferência sobre o mesmo tema. Virginia registra que Pierson "considerou estar ocorrendo um aumento no número de mestiços, através do decréscimo do elemento africano e não do europeu, em vários pontos do Brasil", sugerindo, portanto, que o projeto político-acadêmico de embranquecimento da população brasileira, através do desaparecimento dos negros brasileiros e africano-descendentes, forjado desde os finais do século XIX, estava alcançando seus objetivos, em meados do século XX.

5. Gahyva, 2011explica ostracismo vivido Por Oracy Nogueira e por Virgínia Bicudo a partir do refluxo da perspectiva freyriana de harmonia racial e da paulatina hegemonia da perspectiva de Florestan Fernandes e do francês Roger Bastide sobre as chamadas "relações raciais" no Brasil: "Provavelmente porque, à crítica ao paradigma da democracia racial, sucedeu-se a relativa hegemonia da perspectiva desenvolvida, no mesmo Projeto Unesco, por Florestan Fernandes, tal como elaborada, na sua parceria com Roger Bastide, em Relações raciais entre negros e brancos em São Paulo (Bastide; Fernandes, 1955), e posteriormente refinada em A integração do negro na sociedade de classes (Fernandes, 1965). Em outras palavras, o ocaso da tese da democracia racial cedeu espaço à ideia segundo a qual o preconceito racial corresponderia a um resíduo provocado pela forma abrupta por meio da qual, no Brasil, o "Antigo Regime" cedeu espaço à "ordem social competitiva" (Gahyva, 2011, p. 298)

6. Na entrevista concedida a Chor Maio (2010), organizador e apresentador da publicação da Dissertação de Virgínia Bicudo, ela afirma que via no estudo da sociologia uma via de proteção pessoal contra o racismo: "Desde criança eu sentia preconceito de cor. Queria o curso de sociologia, porque, se o problema era esse preconceito, eu deveria estudar sociologia para me proteger do preconceito, que é formado ao nível sociocultural" (Bicudo, 2010, p. 23 apud Silva, 
2011, p. 443). Será que tentando fugir do racismo da sociedade brasileira através da sociologia, Virgínia foi capturada pelas tramas de um racismo/sexismo epistêmico intrínseco a essa mesma sociologia?

7. A Conferência de Bandung é o nome com o qual ficou conhecido historicamente o encontro ocorrido nesta cidade indonésia entre 18 e 24 de abril de 1955 e que reuniu os líderes de 29 estados asiáticos e africanos, teve como objetivo promover uma cooperação econômica e cultural de perfil afro-asiático, buscando fazer frente ao que na época se percebia como atitude neocolonialista das duas grandes potências, Estados Unidos e União Soviética.

\section{RÉSUMÉS}

Dans cet article, nous envisageons contribuer à la consolidation du champ académique décolonial à partir d'une perspective noire-brésilienne en Amérique Latine, en présentant deux intellectuels noirs invisibles dans le champ des sciences sociales au Brésil - Virgínia Leone Bicudo et Guerreiro Ramos. Ils étaient des personnages actifs aux débats socio-anthropologiques du Brésil pendant les années 1940. L'objectif est de présenter leurs pensées, car les deux ont elaboré des arguments décoloniaux qui ont probrablement inauguré l'épistémologie décoloniale dans les Amériques. En tant que penseurs noirs subalternes, ils n'ont pas beaucoup parlé mais ils ont contesté le racisme et le sexisme épistémique de la pensée universitaire brésilienne et ont proposé la deuxième décolonisation du Brésil.

Neste artigo, busca-se contribuir para a consolidação do campo acadêmico decolonial na perspectiva negro-brasileira na América Latina, apresentando dois intelectuais negros invisíveis nas ciências sociais no Brasil - Virgínia Leone Bicudo e Guerreiro Ramos - que viveram o mundo sócgio-antropológico no Brasil, a partir dos anos 40 do século XX. A intenção é colocar em visibilidade seus pensamentos, pois, ambos apresentaram argumentos decoloniais que podem ser configurados como inaugurais de uma epistemologia decolonial nas Américas. Apesar desses intelectuais negros subalternos pouco terem podido falar no ambiente acadêmico-intelectual brasileiro, ambos interpelaram o racismo/sexismo epistêmico das universidades brasileiras e perseguiram uma segunda descolonização do Brasil.

In this article, we seek to contribute to the consolidation of the decolonial academic field in the black-Brazilian perspective in Latin America, presenting two invisible black intellectuals in the social sciences in Brazil - Virgínia Leone Bicudo and Guerreiro Ramos - who lived the socioanthropological Brazil, since the 40s of the 20th century. This work intention is to make their thoughts visible, because both of them presented decolonial arguments that can be configured as inaugurations of a decolonial epistemology in America. Despite these subaltern black intelectuals haven't been able to speak in the Brazilian academic-intellectual environment, both challenged the epistemic racism/sexism of brazilian universities and pursued a second decolonization of Brazil. 
INDEX

Mots-clés : Décolonisation, décolonialité, racisme-sexisme épistémique, connaissances, colonialité

Palavras-chave : Descolonização, decolonial, racismo-sexismo epistêmico, conhecimento, colonialidade

Keywords : Decolonization, decolonial, epistemic racism-sexism, knowledge, coloniality

\section{AUTEUR}

NÁDIA MARIA CARDOSO DA SILVA

Graduação em Antropologia (Universidade Federal da Bahia). Especialização em Direitos Humanos (Universidade Estadual da Bahia). Mestrado em Educação (Universidade Estadual da Bahia). Doutorado em Cultura e Sociedade (Universidade Federal da Bahia). 